\title{
Some of The Physico-Chemical Properties of Yaychi Region Wells And Their Suitability For Human and Animal Use
}

\author{
Sahira Ahmed Mahmood Al-Azzawee ${ }^{1}$, Estabraq Ali Hameed ${ }^{2}$ \\ sahiraazawee@gmail.com ${ }^{1}$, Chemist.tr258@ gmail.com²
} Medical Laboratories Techniques Department, Al-Hawija Technical Institutes,
Northern Technical University, Mosul-Iraq

\begin{abstract}
Groundwater is one of the important sources of providing the human with water for drinking and other purposes. In Iraq, most of the agricultural land far from surface water sources, which forced these farmers to use groundwater wells as a source to cover the needs of the water and uses for different households. Hence, the ground water is a viable solution to provide drinking water. This study aims to show the extended validity of the ground water of six wells in Yaychi Region for various human and animal uses by compared some of their chemical and physical properties with World Health Organization (WHO). Physico-chemical parameters were analyzed for six wells. The statistical SPSS program used for the statistical analysis of the characteristics, the positive relationship (R) between some characteristics be seen such as calcium and total hardness $=(0.952), \mathrm{EC}$ and hardness $=(0.985), \mathrm{SO} 4-2$ and hardness and $\mathrm{pH}=(0.938), \mathrm{EC}$ and $\mathrm{SO}_{4}{ }^{-2}=(0.997), \mathrm{SO}_{4}{ }^{-2}$ and TDS $=(0.976), \mathrm{EC}$ and TDS $=(0.982), \mathrm{EC}$ and $\mathrm{Ca}^{+2}=(0.938)$ and between $\mathrm{Ca}^{+2}$ and $\mathrm{SO}_{4}^{-2}=(0.950)$.
\end{abstract}

Keywords: Well, WHO, Yaychi, water

\section{Introduction}

Groundwater is considered an important source of water supply for humans to meet different needs. The demanding for this source of water increases due to the continuing growth in the number of population, Water from wells were not suitable for human consumption according to WHO standards [1]. The quality of drinking water is very important for public health and prosperity. The successive drought years, as well as the lack of availability of surface water in most places, pay the human to depend on groundwater as a source for water supplied.

S. Adnan and J. Iqbal [2] investigated the assessment of groundwater quality by examining some of the chemical and physical properties of the aquifer area of Peshawar, Pakistan. The measured properties include; $\mathrm{pH}, \mathrm{EC}$, TDS, TH, Alkality, $\mathrm{Ca}^{+2}, \mathrm{Mg}^{+2}$, Turbidity, $\mathrm{NO}_{3}^{-}$and $\mathrm{Cl}^{-}$, the study results show increased concentrations of the investigated characteristics except for nitrates and $\mathrm{pH}$ in the city center.

M. Dhana sekara pandian et al. studied (29) sample of groundwater to determine their suitability for human consumption and they show exceeded specifications for the limits permitted by WHO [3]. Abdulkarem A.M. studied and anions concentration showed that they are among permitted levels for human uses, but $\mathrm{Ca}^{+2}$ concentration was above the permitted level for drink. Which was meaning its necessary to limited chemical treatment before using 
this water for a drink. While for animal uses all studied parameter results were showed its very accepted for livestock and domestic [4].

One of the biggest problems of the developing countries is the pollution of groundwater with various sources of pollution, whether through the raceways, or throw waste or the use of pesticides and agricultural fertilizers or soil which makes them unsuitable for human use [5] G. Cui , Y. Lu et al show that the statistical characteristic of the groundwater hydro-chemical parameters has a large spatial variability caused by aquifer water quality, topography, geomorphology, hydrology, meteorological conditions, and human activities. the agricultural lands far from surface water in Region of the southwest of Kirkuk operated by their population of farmers and some of them live in an agricultural land owned forced these farmers to use groundwater wells as a source to cover their needs of the water and uses different household. This study aims to show the extent validity of the ground water in these areas for various human use and animal by study and evaluate the physical and the chemical of these wells properties in Yaychi Region and comparing it with the values set at the World Health Organization that away $20 \mathrm{~km}$ locate at the southwest of the province of Kirkuk, on the coordinates the global system table(1) as shown in figure(1).

Table 1. World coordinates for wells

\begin{tabular}{r|r}
\hline World coordinates & No. of wells \\
\hline "29.0 1425.6" 26 N35,E044 & 1 \\
"29.1 14N35 26 28.1",E044 & 2 \\
"32.3 14N35 26 32.9",E044 & 3 \\
"27.8 14N35 26 44.6".E044 & 4 \\
"25.9 14N35 26 152.5,E044 & 5 \\
"18.9 14E044 ‘N35 26 52.0" & 6 \\
\hline
\end{tabular}

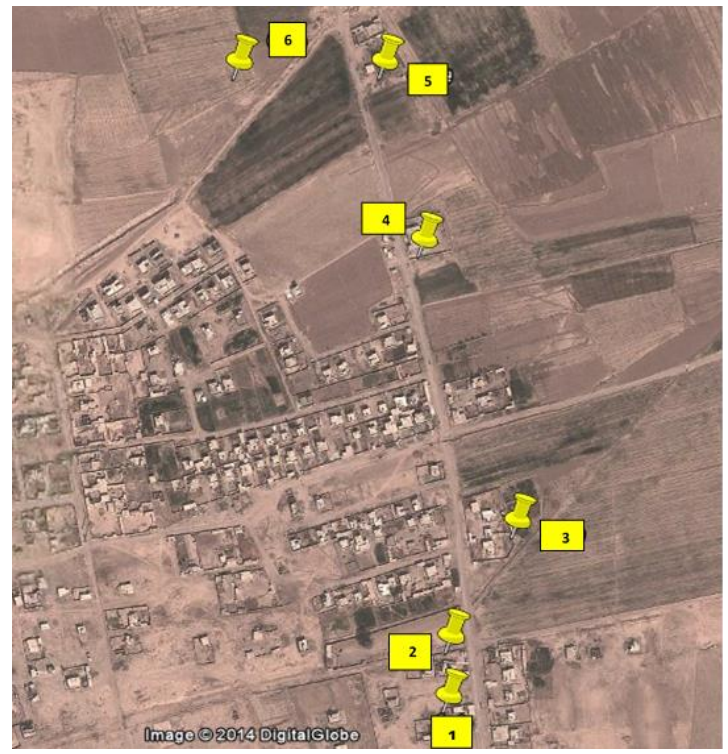

Fig. 1. A map of the wells of study area 


\section{Materials and methods}

2.1 Collection of samples: The samples were collected for examination of physical and chemical properties to the six wells by pumps powered by electricity or diesel engines by running them on the wells for (5-10) minutes and then took the samples (one-liter)which stored in glass bottles according the requirements of the sample [6]. wells Depth ranged between (2050) meters. Chemical and physical tests were conducted and repeated many times for different water samples. Therefore the average of four tests for each property was considered for more accurate results. Micro 100 IR Turbidity meter has been used to measure turbidity and the remote Multi-Parameter PCS Tester Tm 3sto measure the concentration of each of the PH and total dissolved solids and nitrates. The concentrations of total hardness and chloride were measured by titration.

2.2 the results were compared with World Health Organization standards(WHO)[7,8].according to standard methods adopted in the collection, preservation and analysis of samples $[9,10]$.

2.3 Physical and chemical tests: Field and laboratory measurements were carried out according to the standard methods, in the laboratory within $24 \mathrm{hrs}$ with three replications per sample. Turbidity by turbidity meter, Ec by Ec meter, $\mathrm{pH}$ by $\mathrm{pH}$ meter, hardness, calcium, alkality and chloride by titration, $\mathrm{SO}_{4}{ }^{-2}$ by sedimentation, TDS and dehydrating and evaporation method [11-14].

2.4 Data analysis: The results satisfied were collected and were analyzed by a simple Excel method[15].

2.5 Statistical Analysis: (SAS) program was used for the statistical analysis. The least significant difference (LSD test) and T-Test was used to compare between the means of the studied parameters [16].

\section{Results and discussion}

Table 2 and Table 3. show some of the physical and chemical properties such as values of Turbidity, $\mathrm{pH}, \mathrm{Cl}^{-}$and $\mathrm{NO}_{3}^{-}$for $0.33 \%$ of wells are lower than the values stated by the World Health Organization (WHO) $[17,18]$.

TABLE 2. physical and chemical characteristics

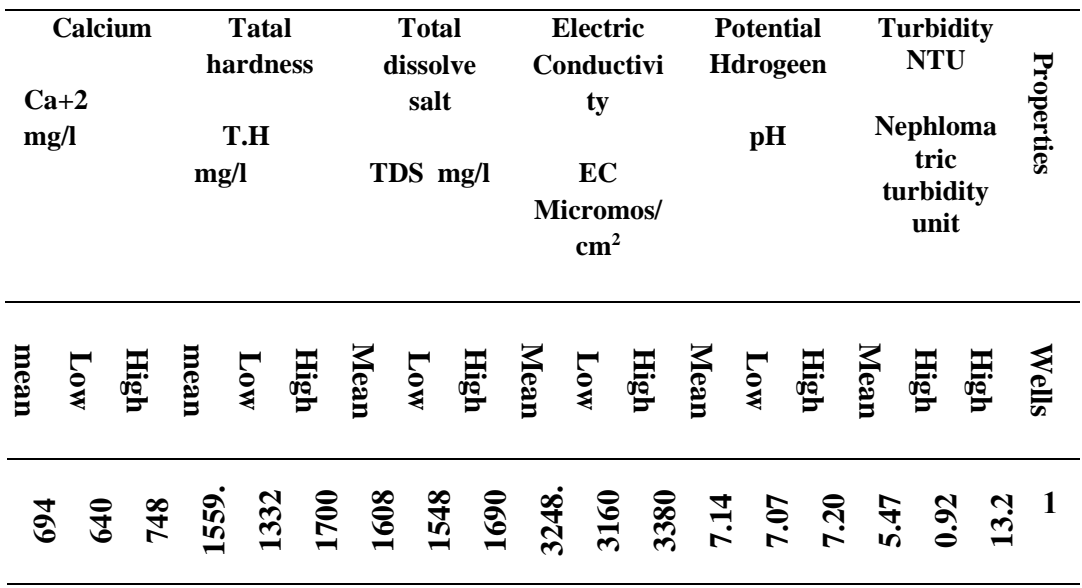




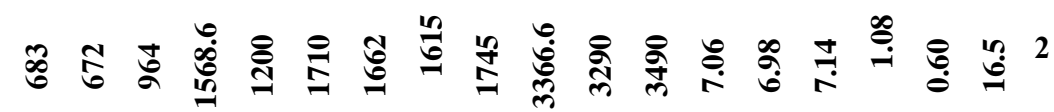

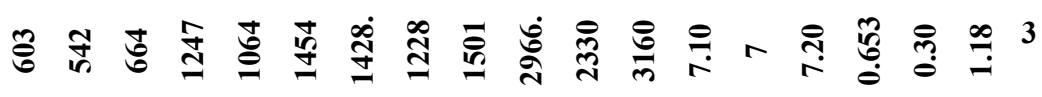

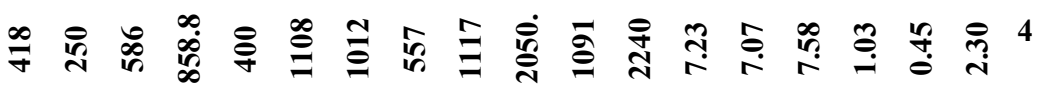

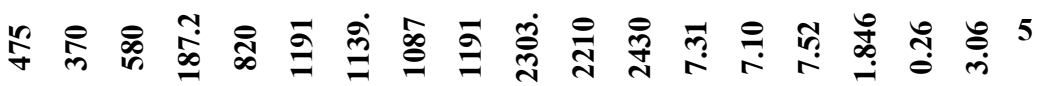

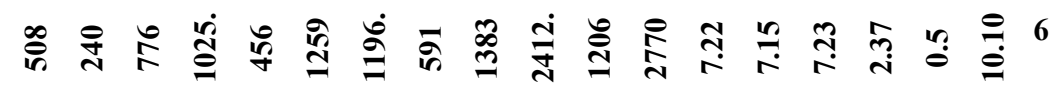

TABLE 3. physical and chemical characteristics

\begin{tabular}{|c|c|c|c|c|c|c|c|c|c|c|c|c|c|c|c|}
\hline \multicolumn{3}{|c|}{$\begin{array}{c}\text { Nitrate } \\
\mathrm{NO}_{3}{ }^{-} \mathrm{mg} / \mathrm{l}\end{array}$} & \multicolumn{3}{|c|}{$\begin{array}{l}\text { Sulphate } \\
\mathrm{SO}_{4}^{-2} \mathrm{mg} / \mathrm{l}\end{array}$} & \multicolumn{3}{|c|}{$\begin{array}{l}\text { Chloride } \\
\mathrm{Cl}^{-} \mathrm{mg} / \mathrm{l}\end{array}$} & \multicolumn{3}{|c|}{$\begin{array}{c}\text { Alkality } \\
\mathrm{HCO}_{3}{ }^{-m g} / 1\end{array}$} & \multicolumn{3}{|c|}{$\begin{array}{l}\text { Magnisium } \\
\mathrm{Mg}^{+2} \mathrm{mg} / 1\end{array}$} & \multirow{2}{*}{ 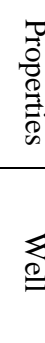 } \\
\hline 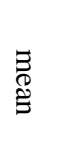 & 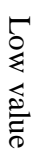 & 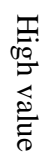 & $\begin{array}{l}3 \\
\mathbb{8} \\
\stackrel{\Xi}{*}\end{array}$ & 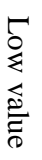 & 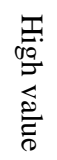 & $\begin{array}{l}\text { ఫ్ } \\
\stackrel{\Xi}{\Xi}\end{array}$ & $\begin{array}{l}5 \\
\vdots \\
\grave{\Sigma} \\
\grave{\Xi}\end{array}$ & 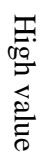 & 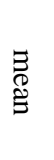 & 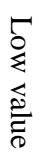 & 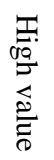 & 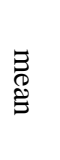 & 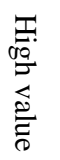 & 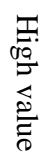 & \\
\hline ث্ঠ & 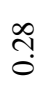 & $\stackrel{n}{i}$ & $\begin{array}{l}\infty \\
\stackrel{\infty}{2}\end{array}$ & $\stackrel{\bar{n}}{=}$ & బิ & શे & 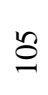 & g & $\begin{array}{l}\text { ָे } \\
\text { तิ }\end{array}$ & $\frac{n}{\sim}$ & లి & $\begin{array}{l}n \\
\infty \\
\infty \\
\infty\end{array}$ & $\frac{2}{6}$ & $\bar{\sigma}$ & 1 \\
\hline $\begin{array}{l}\infty \\
\stackrel{\sim}{0} \\
\text {. }\end{array}$ & $\begin{array}{l}0 \\
\stackrel{0}{0}\end{array}$ & $\forall$ & $\begin{array}{l}\frac{1}{5} \\
8\end{array}$ & mे & $\stackrel{n}{\varrho}$ & 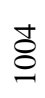 & ล̄ & $\bar{\sigma}$ & 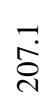 & $\cong$ & $\underset{\sim}{\Delta}$ & 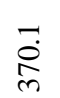 & $\stackrel{\infty}{\sim}$ & ఠ్లి & 2 \\
\hline in & $\ddot{\theta}$ & $\underset{\text { in }}{\infty}$ & $\begin{array}{l}m \\
\infty \\
\infty \\
\infty\end{array}$ & $\begin{array}{l}\text { iñ } \\
\text { in }\end{array}$ & : & in & ஜூׁ & $\underset{\Xi}{ \pm}$ & ֻேं & $\bar{\sim}$ & $\stackrel{P}{\sim}$ & $\hat{0}$ & 告 & $\stackrel{\infty}{\infty}$ & 3 \\
\hline$\vec{~}$ & $\stackrel{\infty}{\stackrel{\circ}{\ominus}}$ & $\vec{n}$ & 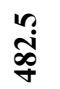 & in & ฉ̊ & 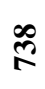 & 8 & $\underset{\square}{ \pm}$ & $\overrightarrow{0}$ & 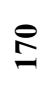 & $\stackrel{ }{\sim}$ & $\frac{n}{7}$ & 은 & $\begin{array}{l}\infty \\
\stackrel{\infty}{\infty}\end{array}$ & 4 \\
\hline 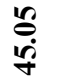 & $\overline{0}$ & $\stackrel{\infty}{\stackrel{0}{\circ}}$ & ָூ & $\ddot{m}$ & $\frac{N}{a}$ & 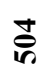 & $\begin{array}{l}\infty \\
\dot{d}\end{array}$ & $\bar{\sigma}$ & స્心 & $\frac{n}{2}$ & $\tilde{\sim}$ & $\stackrel{\circ}{\stackrel{\sigma}{\sigma}}$ & 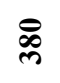 & 䒢 & 5 \\
\hline ڤิ & $\stackrel{\mathscr{c}}{\theta}$ & $\stackrel{\varrho}{\varrho}$ & ָ̃ & $\Xi$ & $\stackrel{\infty}{\varrho}$ & in & ம் & Б용 & $\begin{array}{l}\text { ou } \\
\text { ָ̊ }\end{array}$ & 음 & $\frac{\partial}{2}$ & $\begin{array}{l}\text { 我 } \\
\stackrel{0}{+}\end{array}$ & $\stackrel{0}{\sim}$ & $\tilde{\Xi}$ & 6 \\
\hline
\end{tabular}


All other parameters such as EC, TDS, TH, $\mathrm{Ca}^{+2}, \mathrm{Mg}^{+2}, \mathrm{HCO}_{3}{ }^{-} . \mathrm{Al}_{1}, \mathrm{SO}_{4}^{-2}$ and $\mathrm{NO}_{3}$ - for $0.67 \%$ of wells are higher than (WHO).

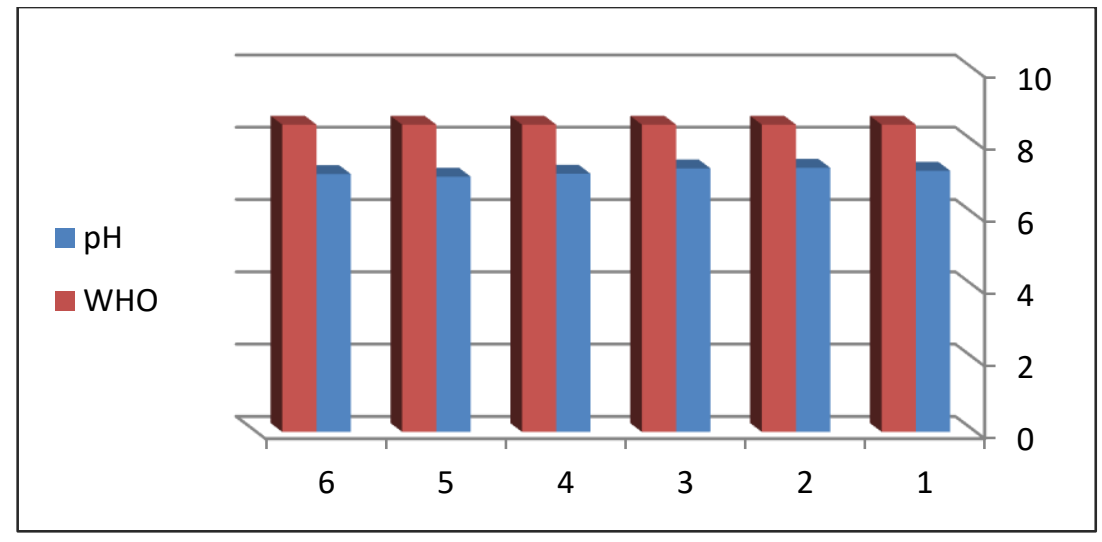

Fig.2. Rate of $\mathrm{pH}$ compare withWHO

Fig. 2. showed the water of the wells is alkali for which the $\mathrm{pH}$ values ranged between "(7.107.31) because of the high value of EC and TDS [5].

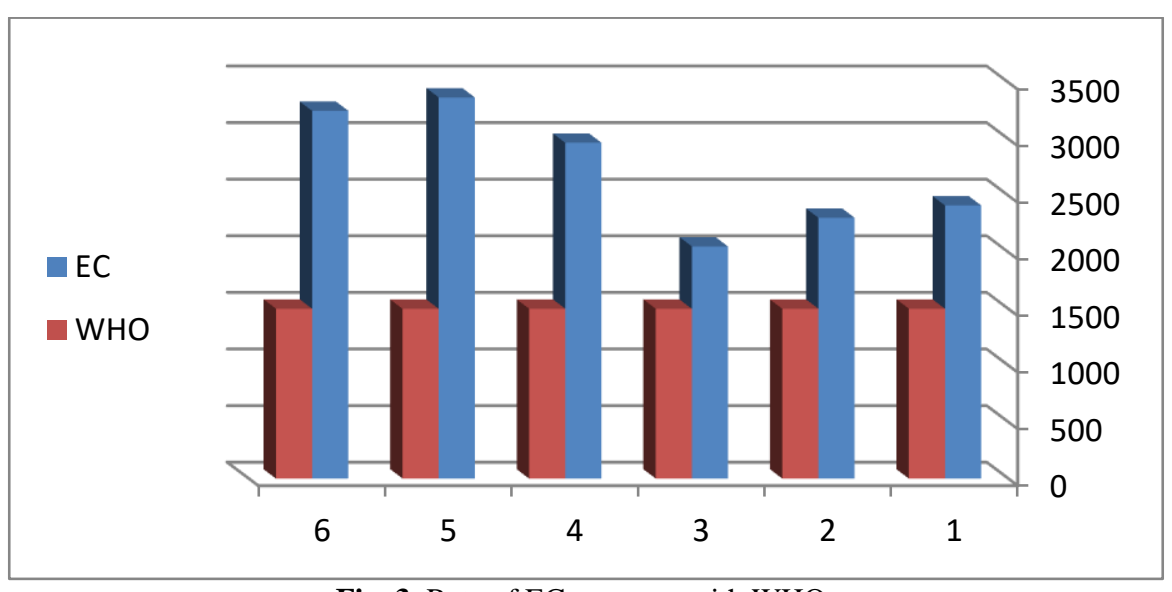

Fig. 3. Rate of EC compare with WHO. 


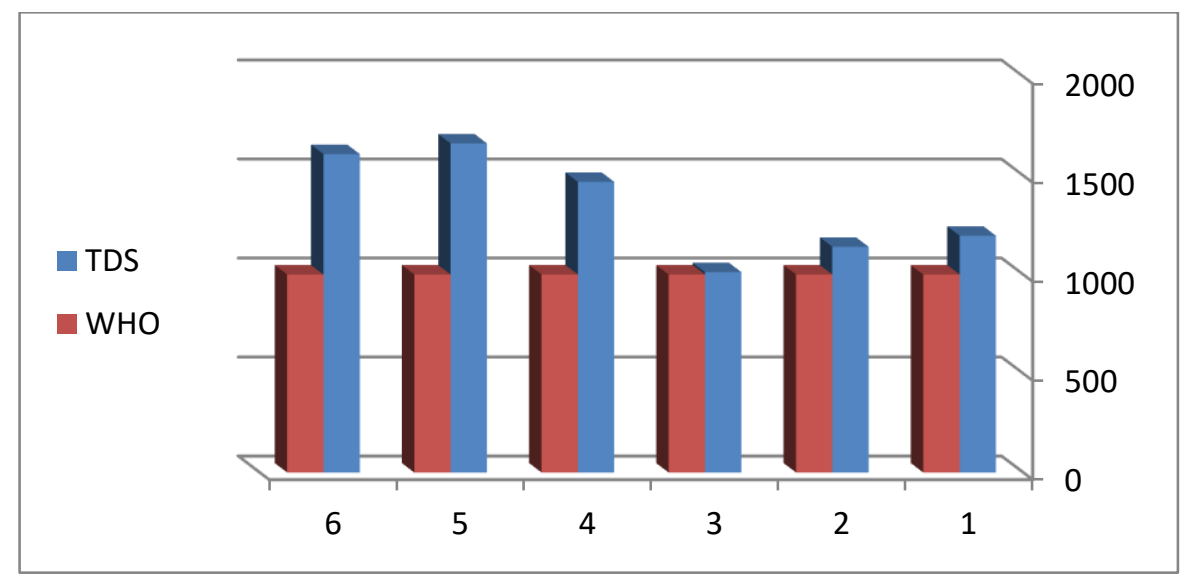

Fig. 4. Rate of TDS compare with WHO.

Figure 4,5. shows that the High value of TDS and EC exceeding the WHO allowable limit for drinking water in all wells water making it unsuitable for use [19,20].

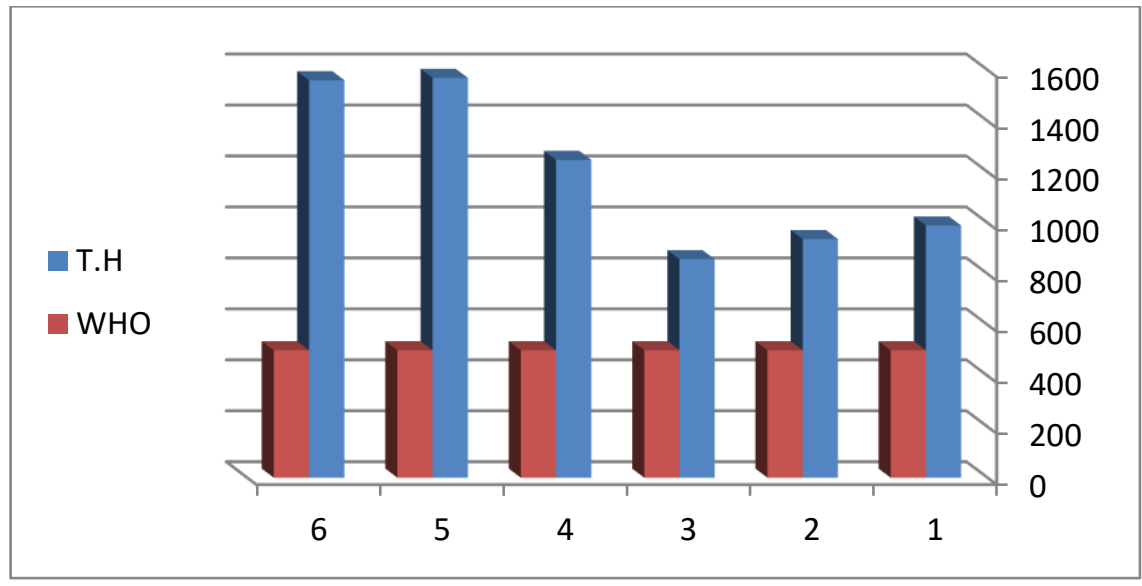

Fig. 5. Rate of TH compare with WHO

Figure 5 shows that the total hardness of wells exceeded the allowable limits and recorded high values and are classified as highly hardness, because of the soil quality. The use of hard water may cause taste undesirable, intestinal disorders [21], increasing soap consumption and closes the pores of the human skin. The use of hard water in the tissue industry, paper and packaging may lead to a decline in the quality of production and the use of hard water for boiler be seals and caused the loss in heat transfer. 


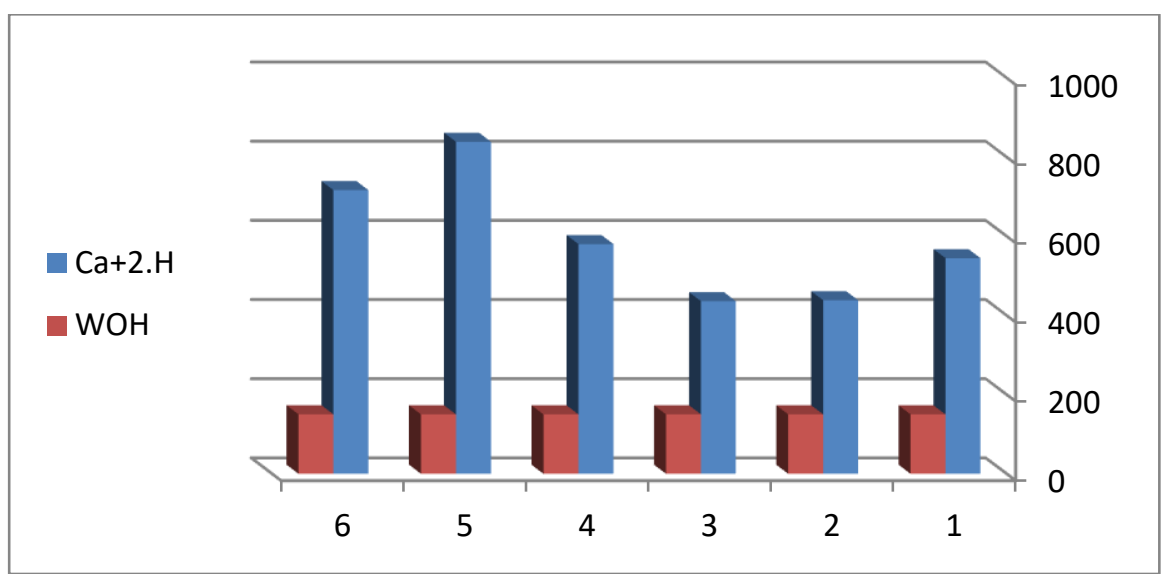

Fig.6. Rate of $\mathrm{Ca}^{+2} \cdot \mathrm{H}$ compare with WHO

Figures 6,7 and 8 illustrate the High level of Hardness ( $\mathrm{Ca} 2+, \mathrm{Mg} 2+)$ and Alkalinity It causes intestinal and skin problems [22]

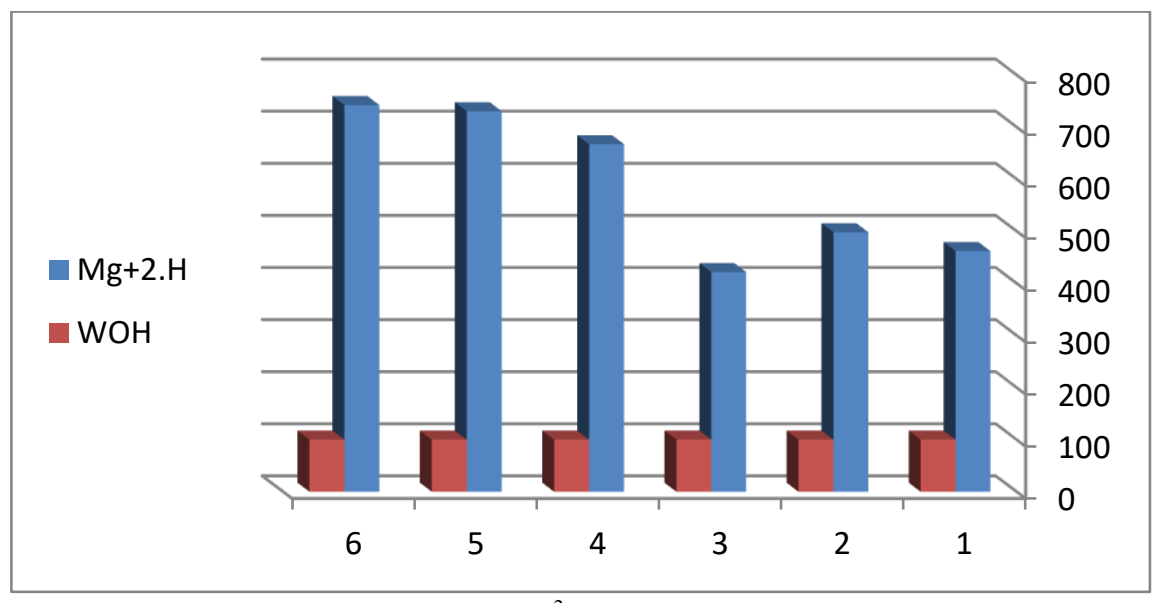

Fig. 7. Rate of $\mathrm{Mg}^{+2}$. $\mathrm{H}$ compare with $\mathrm{WHO}$ 


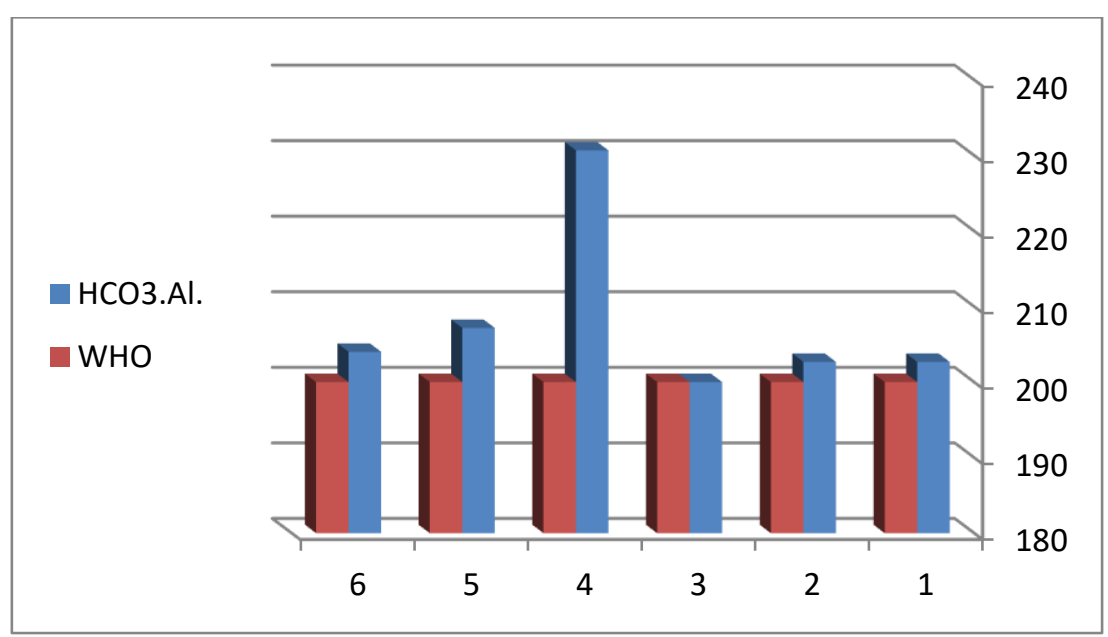

Fig. 8. Rate of $\mathrm{HCO}_{3}$.Al. compare with WHO.

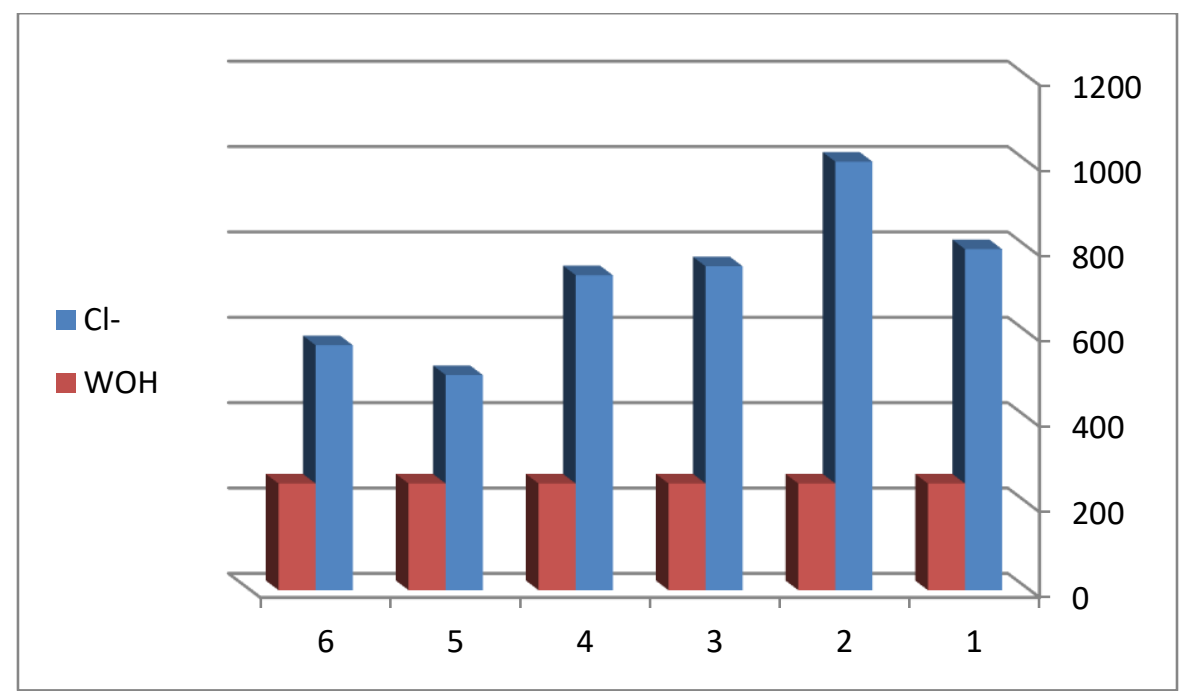

Fig.9. Rate of $\mathrm{Cl}^{-}$. compare with $\mathrm{WHO}$

Figure 9 shows that the High value of $\mathrm{Cl}^{-}$exceeding the WHO allowable limit for drinking water in all wells water making it unsuitable for use [23]. 


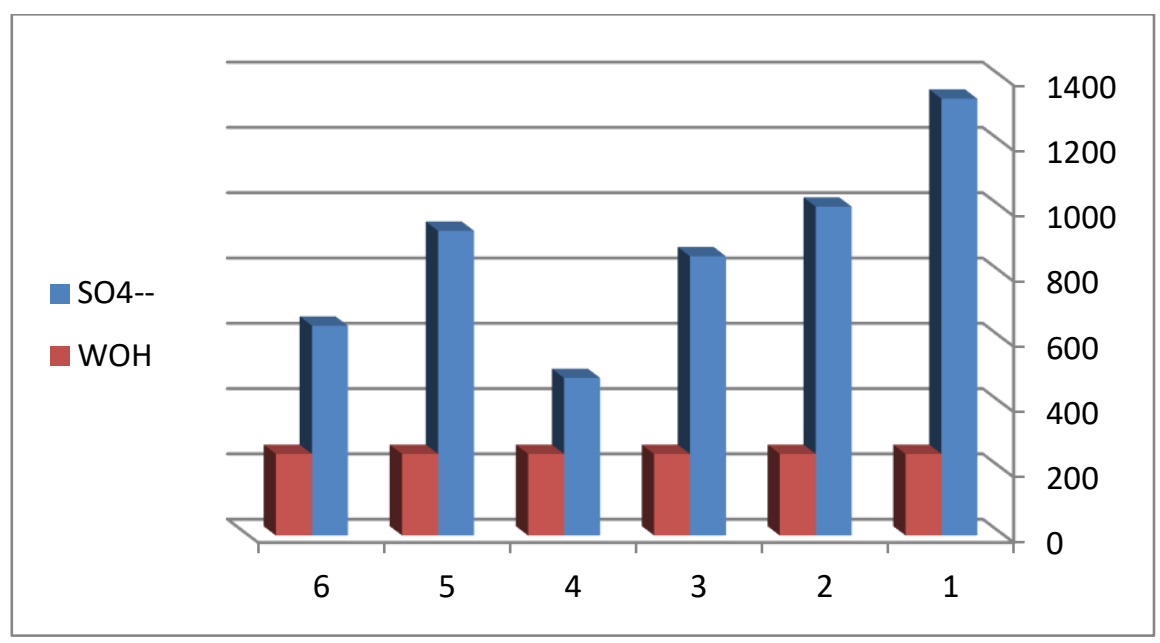

Fig. 10. Rate of $\mathrm{SO}_{4}^{---}$. compare with $\mathrm{WHO}$.

Figure 10 the sulphate of all wells show high value compering with WHO, the source of sulfates in groundwater is mainly due to gypsum or anhydrite. Sulfates can also be produced from the oxidation of sulfur, which is iron sulfide. If the water contains magnesium sulfate and sodium sulfate in large quantities, it will gain bitter taste, as water may gain an easy effect on the human being who He is not used to drinking it [24]. 


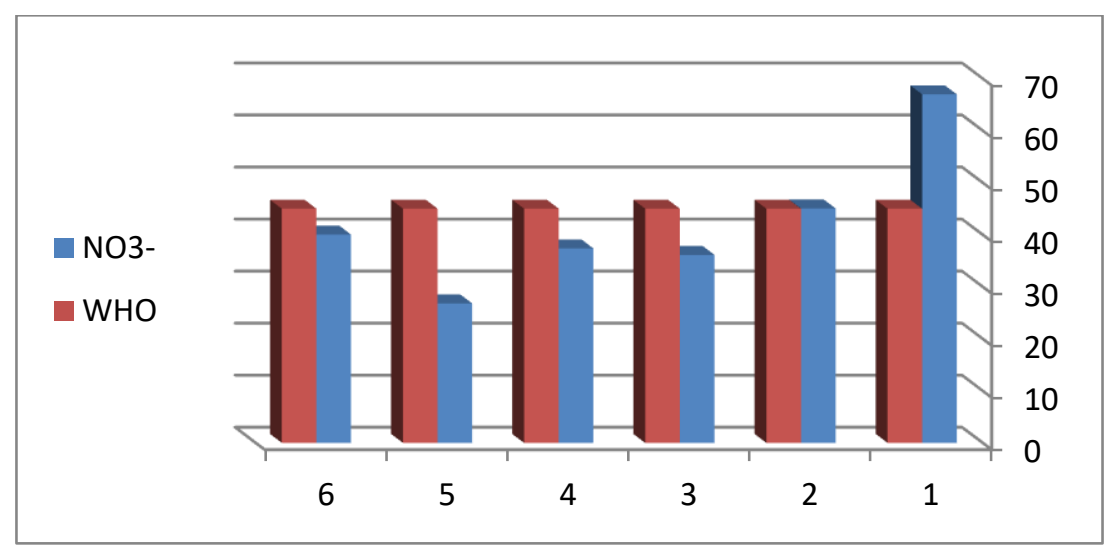

Fig. 11. Rate of $\mathrm{NO}_{3}{ }^{-}$compare with $\mathrm{WHO}$

Figure 11 shows that the water of well (no.1,2) high value of NO3- due to agricultural activities [26]. of wells are located in agricultural areas farmers use the fertilizer and pesticides to combat plantings, Nitrates have a negative impact, particularly on fetuses at the age of three months [27]. The remaining wells showed varying concentrations of nitrate but within limits of WHO.

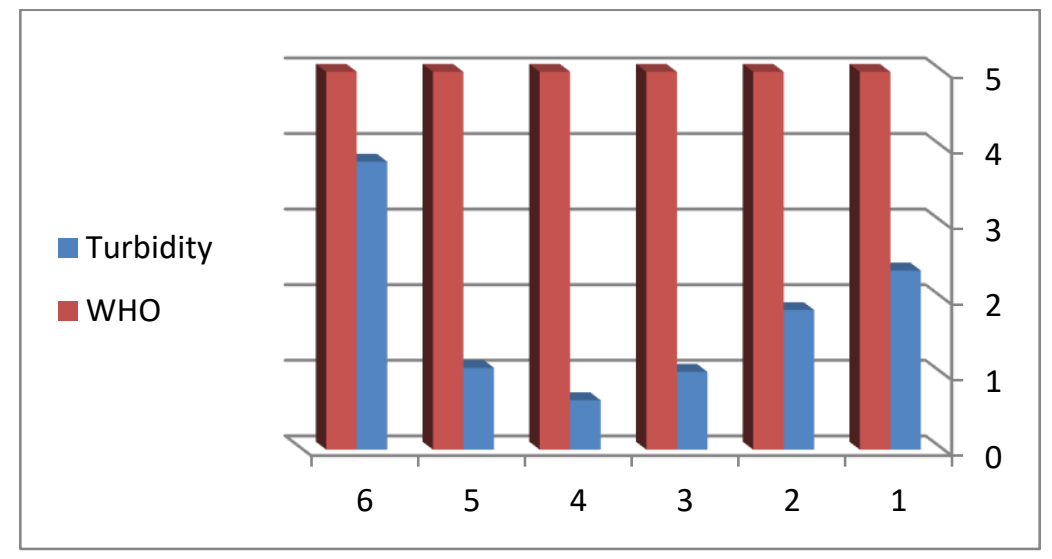

Fig. 12. Rate of Turbidity compare with WHO.

Figure 12 shows that the values of turbidity of all wells are lower than 5 NTU shows that the average turbidity of all wells within the permissible limit values due to leaching property that characterize groundwater and that removes the causes turbidity as clay, silt and other colloidal materials [28].

\section{Statistical Analysis}


A positive relationship $(\mathrm{R})$ between some characteristics be seen in table 4 . such as EC with $\mathrm{TDS}=(0.982), \mathrm{EC}$ with $\mathrm{TH}=(0.985),, \mathrm{EC}$ with $\mathrm{Ca}^{+2}=(0.938)$, TDS with $\mathrm{TH}=\left(0.971^{)}\right.$ and $\mathrm{TH}$ with $\mathrm{Ca}^{+2}=(0.952)$.

TABLE 4. Correlation matrix for wells water ${ }^{\#}$

\begin{tabular}{|c|c|c|c|c|c|c|c|c|c|c|c|}
\hline variable & Turbidity & $\mathrm{pH}$ & $\mathrm{EC}$ & $\mathrm{TDS}$ & $\mathrm{TH}$ & $\mathrm{Ca}^{+2}$ & $\mathrm{Mg}^{+2}$ & $\mathrm{HCO}_{3}^{-}$ & $\mathrm{Cl}^{-}$ & $\mathrm{SO}_{4}^{-2}$ & $\mathrm{NO}_{3}^{-}$ \\
\hline Turbidity & 1 & $-.104-$ & .311 & .336 & .407 & .268 & $-.033-$ & $-.340-$ & .444 & $-.053-$ & .230 \\
\hline $\mathrm{pH}$ & & 1 & $-.948^{* *}$ & $-.891^{*}$ & $-.920^{* *}$ & $-.947^{* *}$ & .208 & $-.461-$ & $-.781-$ & .362 & .447 \\
\hline $\mathrm{EC}$ & & & 1 & $\mathbf{. 9 8 2}$ & $\mathbf{. 9 8 5 ^ { * * }}$ & $\mathbf{. 9 3 8}^{* *}$ & $-.422-$ & .422 & $.894^{*}$ & $-.448-$ & $-.461-$ \\
\hline $\mathrm{TDS}$ & & & & 1 & $\mathbf{. 9 7 1} 1^{* *}$ & $.872^{*}$ & $-.559-$ & .461 & $.855^{*}$ & $-.589-$ & $-.544-$ \\
\hline $\mathrm{TH}$ & & & & & 1 & $\mathbf{. 9 5 2 * *}$ & $-.393-$ & .281 & $.858^{*}$ & $-.437-$ & $-.493-$ \\
\hline $\mathrm{Ca}^{+2}$ & & & & & & 1 & $-.187-$ & .175 & $.814^{*}$ & $-.206-$ & $-.433-$ \\
\hline $\mathrm{Mg}^{+2}$ & & & & & & & 1 & $-.416-$ & $-.375-$ & .685 & .627 \\
\hline $\mathrm{HCO}_{3}^{-}$ & & & & & & & & 1 & .334 & $-.613-$ & $-.221-$ \\
\hline $\mathrm{Cl}^{-}$ & & & & & & & & & 1 & $-.167-$ & $-.101-$ \\
\hline $\mathrm{SO}_{4}^{-2}$ & & & & & & & & & & 1 & .690 \\
\hline $\mathrm{NO}_{3}^{-}$ & & & & & & & & & &. & 1 \\
\hline
\end{tabular}

**. Correlation is significant at the 0.01 level.

\footnotetext{
\# $\quad r=\frac{\sum(X-\bar{X})(Y-\bar{Y})}{\sqrt{\sum(X-\bar{X})^{2}} \sqrt{(Y-\bar{Y})^{2}}}$

Where, $\bar{X}=$ mean of $X$ variable $\bar{Y}$-mean of $Y$ variable
}

TABLE5. water standards for animal use

\begin{tabular}{|l|c|c|c|c|}
\hline Tests & Good & Fair & Moderate & Poor \\
\hline Turbidity & Clear & Clear & & \\
\hline $\mathrm{TDS}(\mathrm{mg} / \mathrm{l})$ & $0-500$ & $500-1000$ & $1000-2000$ & $2000-4000$ \\
\hline $\left.\mathrm{EC} \mu \mathrm{mos} / \mathrm{cm}^{2}\right)$ & $0-800$ & $800-1600$ & $1600-3200$ & $3200-6400$ \\
\hline $\mathrm{Mg}^{+2}(\mathrm{mg} / \mathrm{l})$ & $0-30$ & $30-60$ & $60-120$ & $60-120$ \\
\hline$\left|\frac{\mathrm{Mg}}{12}+\frac{\mathrm{Ca}}{20}\right| \mathrm{meg} / 1$ & & & & \\
\hline $\mathrm{Cl}^{-}(\mathrm{mg} / \mathrm{l})$ & 0.5 & $5-10$ & $10-20$ & $20-40$ \\
\hline $\mathrm{SO}_{4}^{-2}(\mathrm{mg} / \mathrm{l})$ & $0-180$ & $180-360$ & $360-710$ & $710-1420$ \\
\hline
\end{tabular}


TABLE6 . upper limits of total TDS content of water for livestock

\begin{tabular}{lc}
\hline Livestock & TDS (in mg/l) \\
\hline Poultry & 2800 \\
Pigs & 4300 \\
Horses & 6400 \\
Cattle (dairy) & 7100 \\
Cattle (beef) & 10000 \\
\hline
\end{tabular}

The two Tables 4 and 5 show the validity of all wells water are moderated suitable for animal use [29].

\section{Treated methods}

These can be demonstrated as follows:

5.1 Enact legal legislations to combat the random drilling process.

5.2 Not to expand into new agricultural projects, and it is satisfied with the existing management of the water resource

5.3 Carry out periodic analyzes of all produced wells in equal and converged periods

5.4The need to rationalize the consumption of groundwater as it is not renewable, in addition to the fact that over pumping is one of the main causes for increasing the salinization of groundwater in the study area

5.5 roundwater of the study area is unreliable for drinking water supply purposes and therefore puts emphasis on

the need to improve on waste and fertilizer management practices and for curtail the pollution of groundwater.

5.6 Ion exchange technology for the disposal of pathogenic ions and salts in well water

5.7 therefore the six wells water are unsuitable for human use but moderate for animal use. The statistical SPSS program used for the statistical analysis of the characteristics, the positive relationship (R)between some characteristics be seen such as calcium and total hardness = (0.952), $\mathrm{EC}$ and hardness $=(0.985), \mathrm{SO} 4-2$ and hardness and $\mathrm{pH}=(0.938), \mathrm{EC}$ and $\mathrm{SO}_{4}{ }^{-2}$ $=(0.997), \mathrm{SO}_{4}{ }^{-2}$ and TDS $=(0.976), \mathrm{EC}$ and TDS $=(0.982), \mathrm{EC}$ and $\mathrm{Ca}^{+2}=(0.938)$ and between $\mathrm{Ca}^{+2}$ and $\mathrm{SO}_{4}^{-2}=(0.950)$. 


\section{CONCLUSIONS}

In this study

- All other parameters such as EC, TDS, TH, $\left(\mathrm{Ca}^{+2}, \mathrm{Mg}^{+2}, \mathrm{HCO}_{3}{ }^{-} \mathrm{Al}, \mathrm{SO}_{4}{ }^{-2}\right.$ and $\mathrm{NO}_{3}{ }^{-}$for $0.67 \%$ of wells) are found higher than WHO.

- $\quad$ kality of wells water in which the $\mathrm{pH}$ depended on the high value of EC and TDS

- Sulphate of all wells shows high-value comparing with WOH which water may gain an easy effect on the human being that is not used to drinking it.

- The remaining wells showed varying concentrations of nitrate but within limits of WHO.

- The $67 \%$ of wells showed varying concentrations of nitrate but within limits of WHO.

- $\quad$ six wells water are unsuitable for human use but moderate for animal use.

- the positive relationship (R)between some characteristics be seen by statistical SPSS.

\section{ACKNOWLEDGEMENTS}

Thanks and gratitude to everyone who contributed to the completion of this research paper

\section{References}

[1] Wuta, M., Nyamadzawo, G. and Nyamugafata, P.: Ground and Surface Water Quality along a Dambo Transectin Chihota Small Holder Farming Area, Marondera District, Zimbabwe. Physics and Chemistry of the Earth 92. pp.112-118(2015).

[2] Adnan, S., Iqbal J.: Spatial Analysis of the Groundwater Quality in the Peshawar District. Pakistan. Procedia Engineering, 70, pp.14-22, (2014).

[3] Dhanasekarapandian, M., Chandran, S.,et al :Spatial and Temporal Variation of Groundwater Quality And its suitability for Irrigation and Drinking Purpose Using GIS and WQI in an Urban Fringe. Journal of African Earth Sciences, pp.270-288 (2016).

[4] Ali, I., Abdulkarem, A.: Evaluation of Wells Water Suitability of Some Oasis at Iraqi Westerin Region for Human and Animal Uses. Vol.2 No. 1 ,ISSUE.pp.32-37 (2010).

[5] Guoqing, C., Yudong, L., et al: Relationship between Soil Salinization and Groundwater Hydration in Yaoba Oasis, Northwest China. Vol.11 No.1,Water.pp.175 (2019) .

[6] Association, American Public Health. Standard Methods for the Examination of Water and Wastewater. 4thed. (1975).

[7] Guidelines for Drinking Water Quality. Vol. 1, Geneva World Health Organization, IWA Publishing (2008).

[8] APHA, AWWA, WEF. Standard Methods for examination of water and wastewater. 22nd ed. Washington: American Public Health Association, pp.1360. ISBN (2012).

[9] Venkateswaran, S., Deepa, S.: Assessment of Groundwater Quality Using GIS Techniques in Vaniyar Watershed, Ponnaiyar River. Tamil Nadu. Aquatic Procedia 4 (Icwrcoe), pp.83-90(2015).

[10] Mahmood, S. A.: Journal of Anbar University for Pure Sciences (in Arabic Language), Vol.7, no.1, (2013).

[11] Shanmugram K., Nikhila, R. and Janarthanan B.: International Journal for Research in Science \& Advanced Technologies.Vol.1no.1, pp.5-12, (2014).

[12] APHA, standards methods for the examination of water and wastewater.18th ed. (1992).

[13] Khalifa A.H.: Hydraulics of Groundwater and Principles in Surface Water, Balkan Technical University, Amman (in Arabic Language) (1999).

[14] Al-Deen F. Mohammed: Journal of Engineering Sciences.23,1, pp.105 -114 (2016).

[15] Salih, R.A, Diyala journal of Engineering Sciences.12.2, pp.101-109, (2019) 
[16] De-Smith, M., Statsref: Statistical analysis handbook, a web-based statistics resource. The Winchelsea Press, Winchelsea, UK (2015).

[17] F. Mohammed Al-Deen, Journal of Engineering Sciences.No.23,1,105 -114 (2016).

[18] R. A. Salih, Journal of Civil Engineering and Technology (2014)

[19] Aderemi, A., Oriaku, A. et al: Assessment of groundwater contamination by leachate near a municipal solid waste landfill Vol.5 no.11, pp. 933-940.African Journal of Environmental Science and Technology (2011).

[20] Saleh, R.A.: Technical Journal Suitability of Ground Water in Southwest Kirkuk for Human Consumptions, No.13,1,1010(2010).

[21] Zhao, y, Zhang, A., Cheng, C. :Simultaneous removal of nitrate and hardness ions from groundwater using ectrode- ionization .Vol.64,pp. 107-113, science direct ( 2016).

[22] Juan, L.,Anqi, D. et al: Impact of elevated $\mathrm{Ca}^{2+} / \mathrm{Mg}^{2+}$ concentrations of reverse osmosis membrane desalinated seawater on the stability of water pipe materials . Water Health.vol.12 no.1, pp. 24-33 (2014).

[23] AL-Ghawi, A. H.: Removal of Na+ and C1- on surface functionalized dehydrated carbons from date palm leaflets.vol.47, pp.777-780. (2016)

[24] Kiipula, K.: Treatment of sulphate in mine waters: Recycling perspective. Aaulto university, pp. 114126(2016)

[25] Acid rain and its ecological consequences. Journal of Environmental Biology. Vol.29no.1, pp.15-24, (2008).

[26] Stuar, M., Gooddy, et al: A review of the impact of climate change on future nitrate concentrations in groundwater of the UK. vol.409, Issue15, pp. 2859-2873 (2011).

[27] Sadler, R., Brooke, M. et al: Health Risk Assessment for Exposure to Nitrate in Drinking Water from Village Wells in Semarang, Indonesia. Environmental Pollution vol.216, pp.738-745 (2016).

[28] Lantagne ,D., Blount,B.: Disinfection by-product formation and mitigation strategies in point-of-use chlorination of turbid and non-turbid waters in western Kenya. vol.6, Issue1, pp. 67-28 (2008).

[29] Tiki, W., Oba, G.: Transforming Labour and Technology of The Ancient Tula Wells for Watering Livestock In Borana, Ethiopia. White Horse Press. vol.23no.2, pp. 218-240 (2019). 